\title{
Edukasi Resiko Penularan Penyakit Melalui Sampah pada Pemulung Sampah di Tempat Penampungan Sementara Kelurahan Bukit Tunggal Kota Palangka Raya
}

\author{
Education of Risk of Disease Transmission Through Waste for Waste Pickers in Temporary \\ Shelters in Bukit Tunggal, Palangka Raya
}

Suratno*
Nurhalina
Department of Medical
Laboratory Technology,
Universitas Muhammadiyah
Palangkaraya, Palangka Raya,
Central Kalimantan, Indonesia

*email:
suratno.dalim@gmail.com
Kata Kunci
Edukasi
Penularan Penyakit
Pemulung Sampah
Alat Pelindung Diri
Keywords:
Education
Diseases Transmission
Waste Pickers
Personal Protective Equipment
Received: July 2019
Published: September 2019

\begin{abstract}
Abstrak
Kelompok paling beresiko terkena penyakit yang dapat ditularkan melalui sampah adalah pemulung sampah. Para pemulung tidak memiliki pengetahuan dan wawasan yang cukup mengenai pentingnya penggunaan Alat Pelindung Diri saat bekerja. Begitu juga dengan sejumlah pemulung di Tempat Penampungan Sementara yang berada di Kelurahan Bukit Tunggal, Kecamatan Jekan Raya, Palangka Raya. Tujuan kegiatan pengabdian pada masyarakat ini untuk memberikan pendidikan dan pelatihan pengurangan resiko penyebaran penyakit yang dapat ditularkan melalui sampah yang kemungkinan besar ada di Tempat Penampungan Sementara. Kegiatan ini meliputi survei lapangan, wawancara, edukasi dan sosialisasi, pelatihan dan demonstrasi, serta penyerahan seperangkat Alat Pelindung Diri. Solusi yang ditawarkan untuk menyelesaikan prioritas masalah pada pemulung adalah melakukan edukasi serta sosialisasi tentang resiko penyebaran penyakit melalui sampah, edukasi, sosialisasi, pelatihan dan demonstrasi tentang penggunaan Alat Pelindung Diri saat bekerja, dan penyerahan seperangkat alat Alat Pelindung Diri kepada para pemulung. Kegiatan pengabdian kepada masyarakat terhadap 27 pemulung yang tersebar di beberapa Tempat Penampungan Sementara yang berada di Kelurahan Bukit Tunggal, Kota Palangka Raya telah dilaksanakan dengan baik. Hasil survei menunjukkan tingkat penggunaaan Alat Pelindung Diri pemulung sampah, yaitu Tidak Pakai 36,25\%, Pakai Tidak Rutin 16,03\% dan Pakai Rutin 47,5\%. Rangkaian kegiatan ini dapat meningkatkan wawasan pemulung terhadap bahaya penularan penyakit melalui sampah dan cara pencegahannya.
\end{abstract}

\begin{abstract}
Waste pickers are the riskiest group for diseases transmission through waste. Waste pickers have no sufficient knowledge about Personal Protective Equipment usage at work. Likewise, several waste pickers at Temporary Shelters located in Kelurahan Bukit Tunggal, Jekan Raya, Palangka Raya, Indonesia. This community service aimed to provide education and training about the reduction of disease transmission risks through waste at Temporary Shelters. These activities involved field surveys, interviews, education and outreach, training and demonstrations, and distribution of Personal Protective Equipment for waste pickers. The solution offered to solve the problems is to education on disease transmission risks through waste, education, training and demonstration of PPE usage at work, and distribution of Personal Protective Equipment for waste pickers. The community service for 27 waste pickers in several TPS located in Bukit Tunggal was well implemented. The survey result shows the level of usage of Personal Protective Equipment on waste pickers, which is Not Wear $36.25 \%$, Use Non-Routine $16.03 \%$ and Use Routine $47.5 \%$. This series of activities can improve the scavenger's insights into the dangers and prevention of transmitting disease through waste.
\end{abstract}




\section{PENDAHULUAN}

Menurut The Global Alliance of Waste Pickers bahwa ada hampir dua juta jiwa di Indonesia bekerja menjadi pemulung sampah untuk mengumpulkan plastik, logam dan kardus. Pemulung mengumpulkan sampah rumah tangga baik dari tempat sampah rumah warga atau Tempat Penampungan Sementara (TPS) sampah di sepanjang jalan atau di Tempat Pembuangan Akhir (TPA) sampah. Menurut Undang-undang No. 18 Tahun 2008 tentang Pengelolaan Sampah, Tempat Penampungan Sementara adalah tempat sebelum sampah diangkut ke tempat pendaur ulangan, pengelolaan, dan/atau tempat pengelolaan sampah terpadu (Halik et al., 2016).

Sebagian pemulung mencari-cari kebutuhan; yang lain mengumpulkan dan menjual barang daur ulang ke pengepul. Pemulung yang bekerja di TPS-TPS di wilayah kelurahan Bukit Tunggal kota Palangka Raya, selain mengumpulkan plastik, logam dan kardus, mereka juga mengumpulkan makanan sisa untuk pakan ternak. Berbagai jenis sampah ada di dalam TPS yang bercampur menjadi satu sehingga menimbulkan bau tidak sedap. Iswanto et al. (2016) menyimpulkan bahwa jenis Sampah B3 rumah tangga yang banyak ditemukan adalah sampah elektronik (24,91\%), lampu listrik bekas $(18,08 \%)$ dan baterai bekas (16,71\%). Selain itu, tentu saja jenis sampah yang mendominasi di TPS-TPS tersebut adalah sampah rumah tangga yang tidak menutup kemungkinan juga terdapat sampah yang bisa menjadi media penularan penyakit (Apriyani \& Lesmana, 2019). Kondisi tempat kerja yang sangat kumuh dan berbau merupakan sumber berbagai penyakit yang berpotensi menyerang para pemulung (Ceballos \& Burr, 2012). Potensi penyakit yang ada adalah ISPA (Infeksi Saluran Pernapasan Atas), alergi kulit, radang paru-paru, asma, anemia dan lain-lain. Gangguan kesehatan itu disebabkan oleh asap dari pembakaran sampah, tebaran debu sampah, bau busuk yang terbawa angin dan sebagainya (Nisar et al., 2008). Belum lagi potensi tertular oleh penyakit infeksi seperti HIV/AIDS atau penyakit lainnya. Penularan tersebut dapat terjadi melalui jarum suntik yang tertusuk ke tangan ataupun ke telapak kaki (Lestari \& Jufri, 2018). Rendahnya tingkat pemahaman para pemulung tentang resiko penyebaran penyakit melalui sampah seperti: infeksi saluran pernapasan, gangguan saluran pencernaan (disentri, kolera, typhus, dan lain-lain), parasit kecacingan (cacing kremi, cacing gelang, cacing tambang, dan lain-lain), penyakit kulit, penyakit bawaan tikus (leptospirosis), penyakit bawaan nyamuk (demam berdarah, malaria dan filaria), tetanus, HIV/AIDS, dan Hepatitis C (Gutberlet \& Uddin, 2017). Risiko Kesehatan yang dapat terjadi adalah dari kebiasaan sebagian besar pemulung mengkonsumsi makanan sisa yang ditemukan di TPS, menunjukkan bahwa pemulung menanggung risiko rentan kesehatan. Demikian juga terhirupnya gas metan dan bau busuk yang mencemari udara di TPS menyebabkan para pemulung sering merasakan keluhan penyakit seperti sakit kepala, sesak nafas dan ISPA. Kondisi ini semakin diperparah dengan tidak dipergunakannya Alat Pelindung Diri (APD) pada saat bekerja yang sangat sederhana seperti sepatu, topi, masker, sepatu booth dan lain-lain, yang tidak memenuhi persyaratan sebagai pelindung yang dapat memberikan keamanan dan kenyamanan terhadap ancaman gangguan kesehatan (Gutberlet \& Uddin, 2017).

Kesehatan sangat penting namun pemulung mengabaikannya karena alasan tertentu. Semakin diperparah kurangnya perhatian oleh pihak terkait (Dinas Kesehatan/Puskesmas) atau dokter terdekat misalnya sosialisasi atau edukasi kepada para pemulung tentang bahaya resiko penyakit yang mengancam dan APD yang harus digunakan. Belum lagi mengenai aturan atau regulasi yang mengatur mengenai aktivitas 
para pemulung sehingga aspek kesehatan dan keselamatan kerja (International Labour Organization, 2013).

Pada tahun 2013 Program Lingkungan Perserikatan Bangsa-Bangsa (UNEP, United Nations Environment Programme) menyusun Pedoman Kesehatan dan Keselamatan untuk Pemulung Sampah diSudan Selatan (Health and Safety Guidelines for Waste Pickers in South Sudan). Pedoman seperti ini bisa digunakan untuk memandu para pemulung untuk terhindar dari resiko penyakit dan resiko kecelakaan kerja (Cowing, 2013).

Berdasarkan observasi yang telah dilakukan, bahwa sebagian besar dari sekitar 30 orang pemulung yang beroperasi di TPS di kelurahan Bukit Tunggal tidak menggunakan APD seperti dapat dilihat pada Gambar 1 dan Gambar 2. Menurut OSHA atau Occupational Safety and Health Administration (2004), personal protective equipment atau APD didefinisikan sebagai alat yang digunakan untuk melindungi pekerja dari luka atau penyakit yang diakibatkan oleh adanya kontak dengan bahaya (hazards) di tempat kerja, baik yang bersifat kimia, biologis, radiasi, fisik, elektrik, mekanik dan lainnya.

Sebuah penelitian terhadap status kesehatan para pemulung Afrika Selatan, bahwa para pemulung terkena beberapa penyakit yang berhubungan dengan pernafasan. Sebanyak 43\% pemulung meyakini bahwa kesakitan mereka karena kondisi pekerjaan, sedangkan 34\%-nya bukan karena kondisi kerja yang buruk. Sekitar 19\% pemulung meyakini kesakitan mereka tidak ada hubungannya dengan pekerjaan mereka di sekitar sampah (Mothiba et al., 2017).

Menurut Coelho et al. (2016), para pemulung wanita yang mengumpulkan sampah terpapar pada kondisi kerja yang berbahaya dan memiliki potensi resiko kesehatan. Berkaitan dengan akses ke pelayanan kesehatan, 36,9\% pemulung sampah tidak berkonsultasi ke dokter lebih dari 1 tahun, 15,7\% tidak mempunyai akses ke unit kesehatan masyarakat, 7,5\% tidak pernah mengukur tekanan darah, 45,9\% tidak pernah memeriksa gula darah dan 61,2\% tidak pernah mengukur kadar trigliseridanya (Auler et al., 2014). Padahal hal tersebut sangat penting untuk memantau kesehatan para pemulung.

Berdasarkan uraian di atas, berikut permasalahan para pemulung sampah yang bekerja di TPS di kelurahan Bukit Tunggal kota Palangka Raya. Pertama, para pemulung sampah sangat beresiko terkena penyakit yang dapat ditularkan melalui sampah. Penyakit yang bisa mengancam para pemulung seperti: infeksi saluran pernapasan, gangguan saluran pencernaan (disentri, kolera, typhus, dan lain-lain), parasit kecacingan (cacing kremi, cacing gelang, cacing tambang, dan lain-lain), penyakit kulit, penyakit bawaan tikus (leptospirosis), penyakit bawaan nyamuk (demam berdarah, malaria dan filaria), tetanus, HIV/AIDS, Hepatitis C, dan lainlain. Kedua, para pemulung tidak memiliki pengetahuan dan wawasan yang cukup mengenai pentingnya penggunaan APD sehingga banyak dari mereka yang tidak menggunakan APD saat bekerja. Pemulung perlu edukasi tentang APD dan pentingnya penggunaan APD. Ketiga, salah satu cara pengurangan resiko penyebaran penyakit melalui sampah adalah dengan edukasi dan pendampingan tentang penggunaan APD. Melalui kegiatan tersebut dapat mengurangi dan mencegah terjadinya kecelakaan kerja yang berdampak pada pengurangan resiko penyebaran penyakit.

Tujuan kegiatan pengabdian pada masyarakat ini untuk memberikan pendidikan dan pelatihan pengurangan resiko penyebaran penyakit yang dapat ditularkan melalui sampah yang kemungkinan besar ada di TPS. Kegiatan ini dilakukan terhadap sejumlah pemulung yang bekerja mengumpulkan sampah di TPS-TPS yang berada di Kelurahan Bukit Tunggal, Kecamatan Jekan Raya, Kota Palangka Raya. 


\section{METODOLOGI}

Alat dan bahan yang digunakan dala kegiatan pengabdian kepada masyarakat ini yaitu, (1) modul yang digunakan sebagai alat peraga dalam mengedukasi tentang penularan penyakit melalui sampah dan penggunaan APD; (2) angket, yang berisi pertanyaan tentang identitas diri, kegiatan pemulung, riwayat penyakit, tingkat penggunaan APD, dan lain-lain; dan (3) perangkat APD, seperti sarung tangan dan masker sebagai alat peraga dan untuk dibagikan kepada pemulung sampah.

Solusi yang ditawarkan untuk menyelesaikan prioritas masalah pada pemulung di TPS di wilayah kelurahan Bukit Tunggal Kota Palangka Raya adalah dengan melakukan: (1) edukasi serta sosialisasi tentang resiko penyebaran penyakit melalui sampah, (2) edukasi, sosialisasi, pelatihan dan demonstrasi tentang penggunaan APD saat bekerja, dan (3) penyerahan seperangkat alat APD kepada para pemulung.

Kegiatan edukasi dan sosialisasi dilakukan untuk memberikan pemahaman kepada para pemulung tentang penyakit-penyakit yang bisa ditularkan melalui sampah, jenis-jenis sampah, dan resiko penyebaran penyakit yang bisa menjangkit melalui sampah yang sering ada di TPS. Dengan demikian, para pemulung mempunyai wawasan dan pengetahuan yang cukup untuk megurangi resiko penyakit yang bisa ditularkan melalui sampah. Kegiatan edukasi dan sosialisasi juga dilakukan untuk memberikan pemahaman kepada para pemulung tentang $A P D$, jenis-jenis $A P D$, fungsi APD dan lain-lain. Selain itu kegiatan tersebut bertujuan untuk menanamkan kesadaran kepada diri pemulung terhadap pentingnya penggunaan APD saat bekerja.

Kegiatan pelatihan dan demonstrasi dilakukan untuk melatih kemampuan para pemulung menggunakan serangkaian APD secara praktek sehingga terampil menggunakannya. Kegiatan penyerahan seperangkat alat APD kepada para pemulung dilakukan untuk merangsang kesadaran para pemulung tentang pengguaan APD dalam rangka pengurangan resiko penularan penyakit melalui sampah di TPS.

\section{HASIL DAN PEMBAHASAN}

Kegiatan pengabdian kepada masyarakat ini dilakukan terhadap para pemulung yang beraktivitas di beberapa titik TPS yang tersebar di kelurahan Bukit Tunggal, Palangka Raya. Pelaksanaan kegiatan PKM ini meliputi beberapa tahapan, yaitu persiapan, pelaksanaan pendampingan dan evaluasi program.

Tahap persiapan meliputi persiapan alat dan bahan, survei lapangan dan wawancara. Survei lapangan dilakukan dengan mendata tiap-tiap TPS di kelurahan Bukit Tunggal dimana para pemulung bekerja. Kegiatan ini dilakukan di 9 TPS di kelurahan Bukit Tunggal Kota Palangka Raya yang disajikan pada Tabel I.

Tabel I. Daftar TPS di kelurahan Bukit Tunggal Kota Palangka Raya

\begin{tabular}{cll}
\hline No & \multicolumn{1}{c}{ Alamat TPS } \\
\hline 1 & TPS Jalan Rajawali IX / Pengaringan \\
2 & TPS Jalan Bakut \\
3 & TPS Jalan Rajawali (Depan Puskesmas \\
& Pondok Cahaya Emas) \\
4 & TPS Jalan Rajawali (Depan Komplek \\
& Rajawali Permai) & \\
5 & Kontainer Jalan Hiu Putih IV & \\
6 & TPS Jalan Hiu Putih X \\
7 & TPS Jalan Tjilik Riwut Km 8 (Depan \\
& Terminal Lama) \\
8 & TPS Jalan Tjilik Riwut Km 9 \\
9 & Kontainer Jalan Badak (Simpang Jalan \\
& Rajawali) \\
\hline
\end{tabular}

Wawancara dilakukan terhadap para pemulung (Gambar 1) untuk menggali informasi pengetahuan awal para pemulung. Kegiatan ini dilakukan untuk menggali identitas, karakteristik pemulung, riwayat penyakit, pengetahuan dan wawasan pemulung terhadap resiko penyakit menular, pengetahuan dan penggunaan APD. Wawancara dilakukan dengan 
panduan instrumen angket. Dari proses wawancara akan diperoleh informasi mengenai bagaimana para pemulung terhadap resiko penyakit menular dan APD.

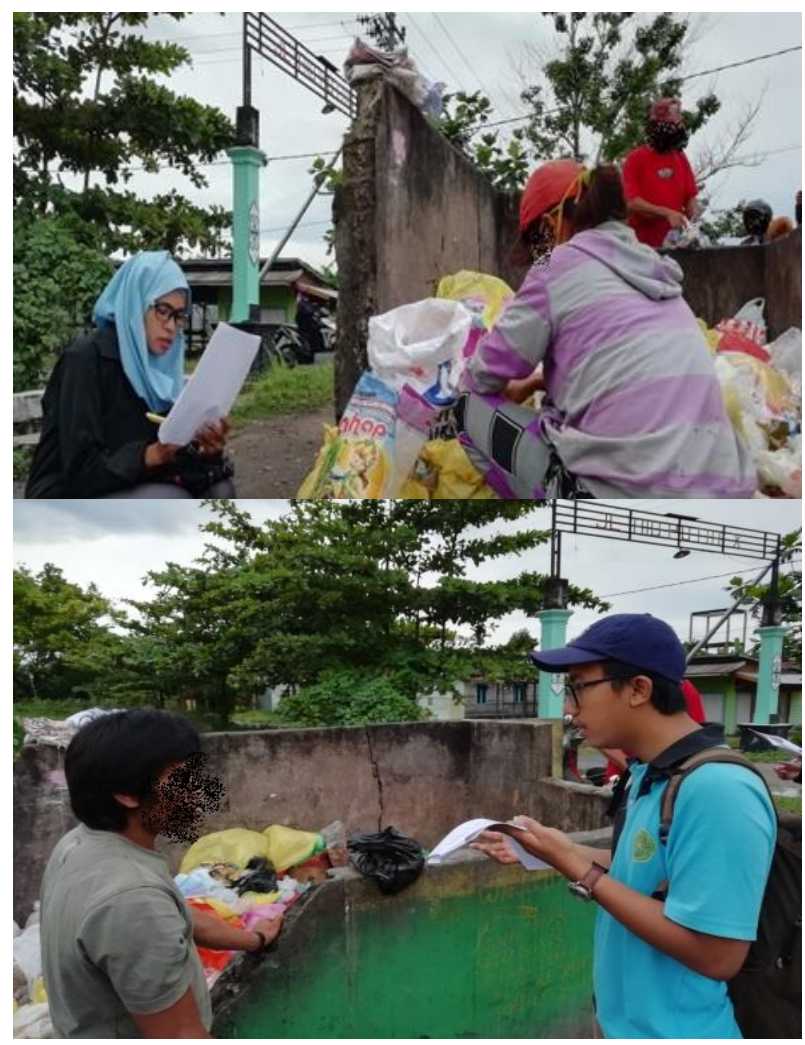

Gambar 1. Kegiatan wawancara pemulung di TPS oleh anggota tim pengabdian (atas) dan ketua tim pengabdian (bawah)

Berdasarkan pengisian angket melalui wawancara terhadap pemulung diperoleh hasil yang disajikan pada Gambar 2. Gambar tersebut menunjukkan rendahnya penggunaan APD pada pemulung. Penggunaan APD yang paling rendah adalah penggunaan apron atau jaket pelindung. Sebanyak 88,9\% pemulung tidak memakai APD jenis ini. Hampir separuh pemulung tidak menggunakan masker, sarung tangan, dan alat pengait sampah. Masker yang dipakai rutin oleh 40,7\% pemulung merupakan masker-sekali-pakai yang telah digunakan berulang-ulang sehingga tidak sesuai standar kesehatan dan keselamatan kerja (K3). Sebanyak 29,6\% pemulung yang rutin menggunakan sarung tangan ini sebenarnya tidak menggunakan sarung tangan standar, namun para pemulung ini menggunakan plastik/kresek yang menutupi permukaan tangan dan diikat menggunakan tali. Hanya 29,6\% pemulung yang rutin menggunakan alat pengait sampah, yaitu alat untuk mengais sampah sehingga sampah tidak bersentuhan langsung dengan tangan. Penggunaan rutin APD yang tinggi adalah penutup kepala $(59,3 \%)$ dan sepatu pengaman $(55,6 \%)$. Namun, sebagian pemulung yang menggunakan sepatu masih belum memakai sepatu booth.

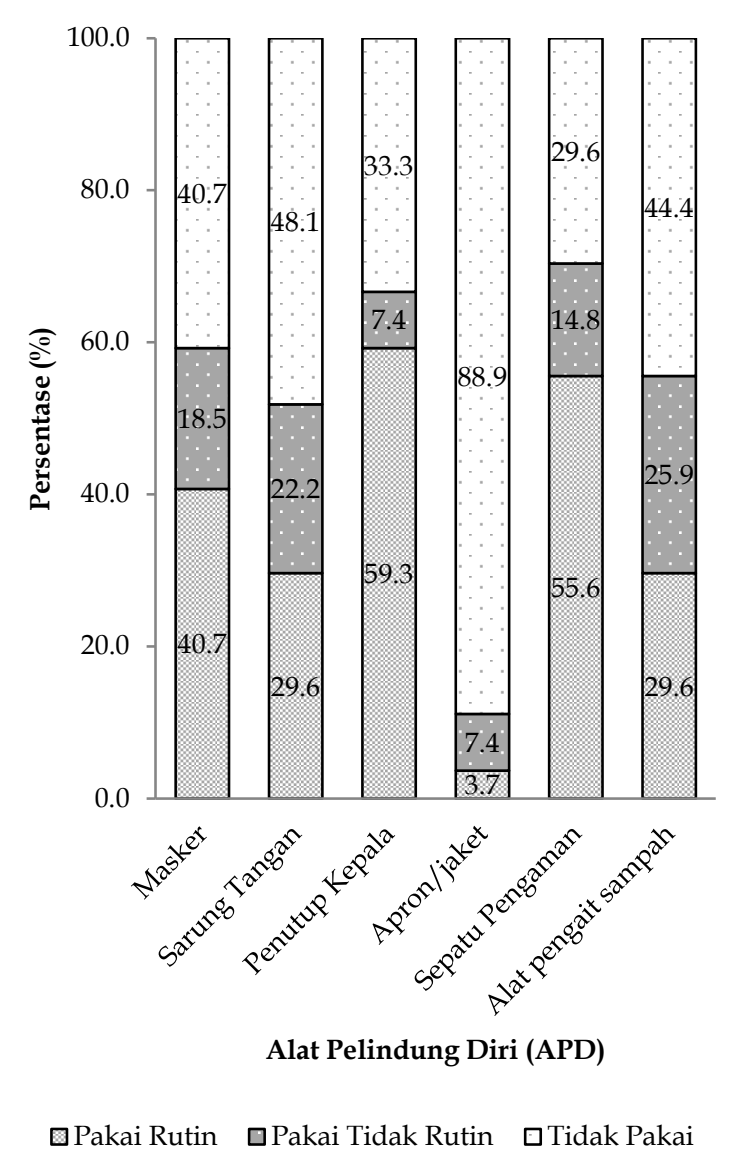

Gambar 2. Tingkat penggunaan APD pada
pemulung

Tahap pelaksanaan pendampingan meliputi edukasi dan sosialisasi, demonstrasi dan pemberian bantuan Alat Pelindung Diri (Gambar 3). Kegiatan edukasi dan sosialisasi dilakukan dengan cara memberikan pengetahuan kepada para pemulung melalui ceramah dan tanya jawab. Kegiatan ini dilakukan untuk memberikan pemahaman kepada para pemulung tentang: (1) jenis-jenis sampah; (2) penyakit-penyakit yang bisa ditularkan melalui sampah; (3) Jenis-jenis Alat 
APD dan fungsinya; (4) Pentingnya penggunaan APD saat bekerja; dan (5) pengurangan resiko penyebaran penyakit yang bisa menjangkit melalui sampah yang sering ada di TPS.

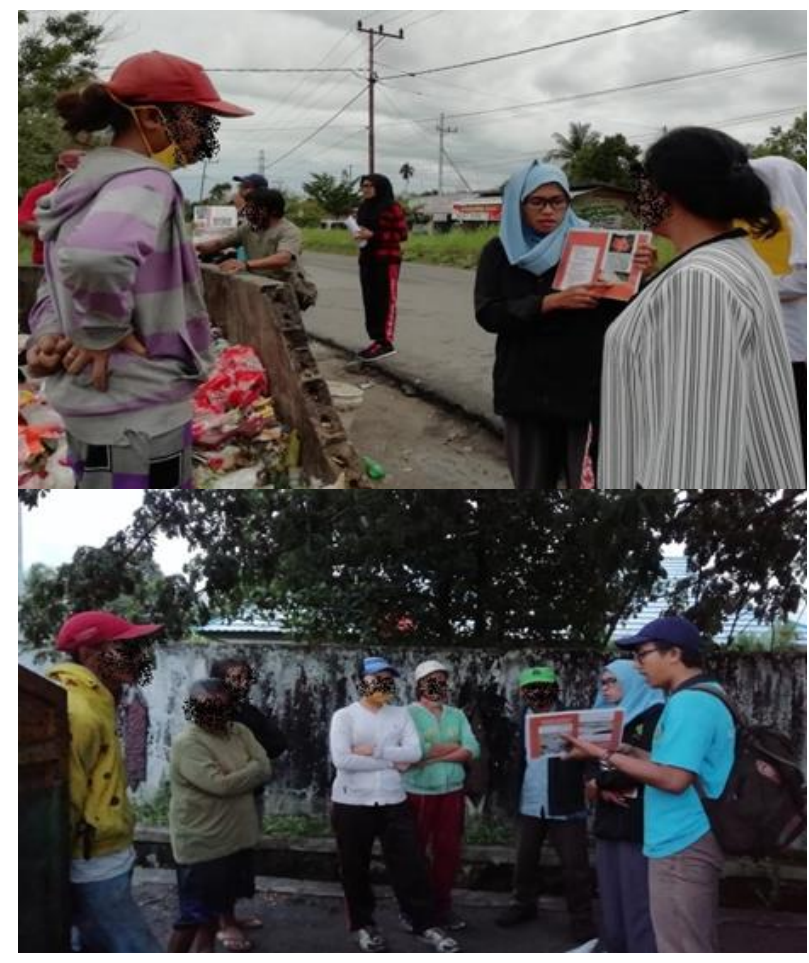

Gambar 3. Kegiatan edukasi dan sosialisasi kepada pemulung di beberapa titik TPS oleh anggota tim pengabdian (atas) dan ketua tim pengabdian (bawah)

Resiko kecelakaan kerja ataupun penularan penyakit melalui sampah sangat rentan terjadi pada pemulung yang sering kontak dengan sampah. Penggunaan APD yang benar dapat menurunkan resiko-resiko tersebut. Kegiatan pelatihan dan demonstrasi penggunaan APD (Gambar 4) dilakukan melalui pelatihan dan praktek langsung oleh tim dan para pemulung. Kegiatan ini untuk melatih para pemulung menggunakan APD dengan baik dan benar, sehingga dapat melindungi pemulung dari kecelakaan kerja atau penularan penyakit. Pardiansyah (2015) menjelaskan bahwa pada pemulung yang selalu berkontak dengan sampah yang mengandung bahan-bahan kontaktan seperti rubber, kertas, beberapa bahan kayu, dan kaca sangat berisiko untuk menderita Penyakit Kulit Akibat Kerja, yakni 50\% dari jumlah seluruh penderita Penyakit Kulit Akibat Kerja terutama dermatitis kontak.

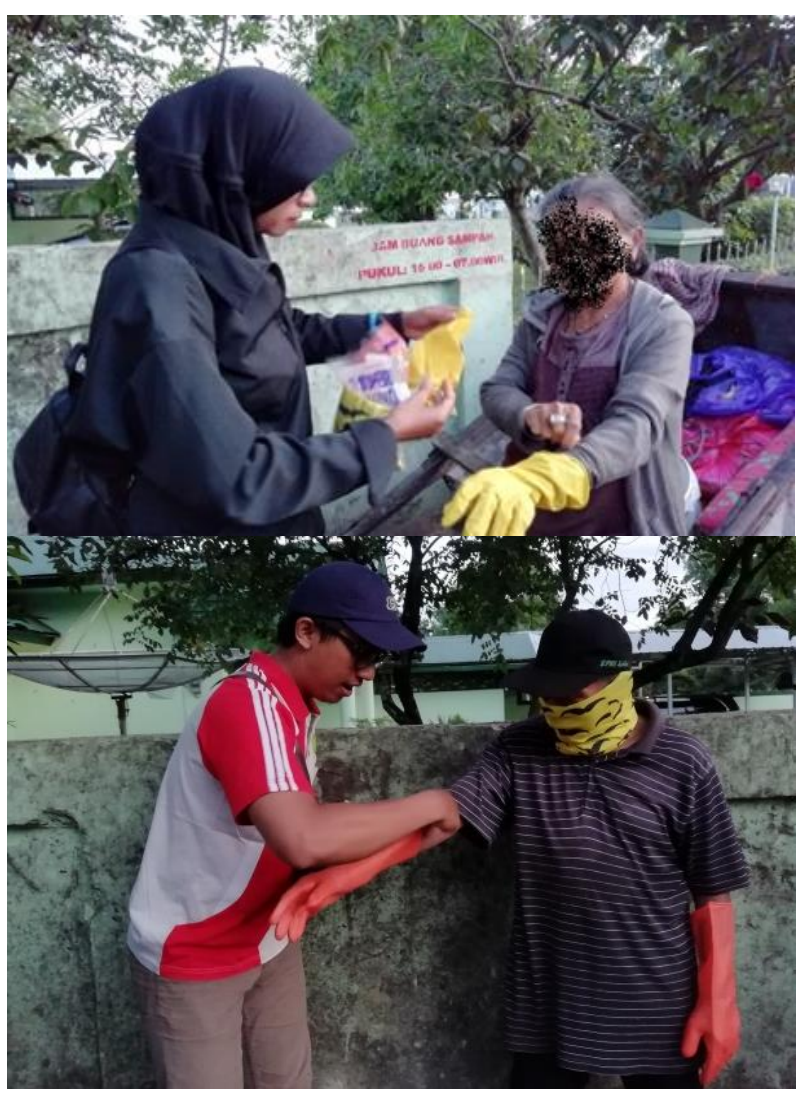

Gambar 4. Pembagian APD oleh anggota tim pengabdian kepada pemulung (atas) dan demonstrasi cara penggunaan APD oleh ketua tim pengabdian (bawah)

Kegiatan penyerahan seperangkat alat APD kepada para pemulung dilakukan sebagai langkah awal terhadap upaya mengurangi bahaya sampah bagi kesehatan. Hal ini juga dilakukan untuk merangsang kesadaran para pemulung tentang pengguaan APD dalam rangka pengurangan resiko penularan penyakit melalui sampah di TPS. Menurut Mulyanasari dan Mulyono (2019), masalah kesehatan dan kecelakaan kerja pengumpul sampah beragam mulai dari masalah pernapasan, masalah muskuloskeletal, penyakit menular dan tidak menular, masalah mental dan masalah lainnya hingga berdampak pada keluarga mereka dan menyebabkan kematian. Diperlukan kebijakan yang mengatur kesehatan dan keselamatan kerja pengumpul sampah serta peningkatan pengetahuan kesehatan dan 
keselamatan kerja, pengadaan alat pelindung diri dan meningkatkan kepatuhan penggunaan alat pelindung diri oleh pengumpul sampah melalui peran pelayanan kesehatan.

\section{KESIMPULAN}

Kegiatan pengabdian kepada masyarakat terhadap 27 pemulung yang tersebar di TPS-TPS yang berada di Kelurahan Bukit Tunggal, Kota Palangka Raya telah dilaksanakan dengan baik. Kegiatan ini meliputi survei lapangan, wawancara, edukasi dan sosialisasi, pelatihan dan demonstrasi, serta penyerahan seperangkat APD. Edukasi dan sosialisasi tentang jenis-jenis sampah, penyakit yang ditularkan melalui sampah, APD dan fungsinya, pentingnya penggunaan APD untuk menurunkan resiko penularan penyakit melalui sampah. Pelatihan dan demonstrasi dalam penggunaan APD terhadap pemulung dalam upaya meningkatkan keterampilan dan kesadaran pemulung dalam menggunakan APD dengan baik dan benar. Rangkaian kegiatan ini dapat meningkatkan wawasan pemulung terhadap bahaya penularan penyakit melalui sampah dan cara pencegahanya. Kegiatan pengabdian kepada masyarakat seharusnya digalakkan oleh setiap lapisan masyarakat, baik masyarakat maupun dinas-dinas terkait dalam upaya meningkatkan derajat kesehatan masyarakat. Perhatian pemerintah terhadap kelompok masyarakat miskin, minoritas dan marginal seperti pemulung perlu ditingkatkan guna mencapai keadilan sosial.

\section{UCAPAN TERIMA KASIH}

Penulis mengucapkan terima kasih kepada pihak Lembaga Penelitian dan Pengabdian kepada Masyarakat Universitas Muhammadiyah Palangkaraya yang telah mendanai kegiatan ini melalui Hibah Pengabdian Kepada Masyarakat dengan skema
Program Kemitraan Masyarakat Stimulus (PKMS) Tahun 2018 sesuai dengan Surat Perjanjian Penugasan Pelaksanaan Pengabdian kepada Masyarakat nomor 409.k/PTM.63.R10/LP2M/P/2018 Tanggal 2 Juli 2018.

\section{REFERENSI}

Apriyani, N., Lesmana, R.Y. 2019. Jumlah Timbulan dan Komposisi Sampah di Kelurahan Pahandut Kota Palangka Raya serta Dampaknya terhadap Kualitas Air Lindi. Media Ilmiah Teknik Lingkungan (MITL). 4(1):5-9. https://doi.org/10.33084/mitl.v4i1.648

Auler, F., Nakashima, A.T., Cuman, R.K. 2014. Health conditions of recyclable waste pickers. Journal of Community Health. 39(1):17-22. https://doi.org/10.1007/s10900-013-9734-5

Ceballos, D.M., Burr, G.A. 2012. Evaluating a Persistent Nuisance Odor in an Office Building. Journal of Occupational and Environmental Hygiene. 9(1):D1-D6. https://dx.doi.org/10.1080/15459624.2012.63 5131

Coelho, A.P., Beck, C.L., Fernandes, M.N., Freitas, N.Q., Prestes, F.C., Tonel, J.Z. 2016. Women waste pickers: living conditions, work, and health. Revista Gaúcha de Enfermagem. 37(3):e57321. https://doi.org/10.1590/19831447.2016.03.57321

Cowing, M.J. 2013. Health and Safety Guidelines for Waste Pickers in South Sudan. South Sudan: United Nations Environment Programme.

Gutberlet, J., Uddin, S.M.N. 2017. Household waste and health risks affecting waste pickers and the environment in low- and middle-income countries. International Journal of Occupational and Environmental Health. 23(4):299-310. https://doi.org/10.1080/10773525.2018.14849 96

Halik, A., Perdana, D., Prasnowo, M.A. 2016. Peningkatan Usaha Pengepul Barang Bekas di Kota Surabaya. JPM17: Jurnal Pengabdian Masyarakat. 2(1):29-38. https://doi.org/10.30996/jpm17.v2i01.1037

International Labour Organization. 2013. Keselamatan dan Kesehatan Kerja di Tempat Kerja: Sarana untuk Produktivitas. Modul Lima Pedoman pelatihan 
untuk manajer dan pekerja. Jakarta: International Labour Organization.

Iswanto, I., Sudarmadji, S., Wahyuni, E.T., Sutomo, A.H. 2016. TimbulanSampah B3 Rumahtangga dan Potensi Dampak Kesehatan Lingkungan di Kabupaten Sleman, Yogyakarta. Jurnal Manusia dan Lingkungan (Journal of People and $\begin{array}{ll}\text { environtment). } & \text { 23(2):179-188. }\end{array}$ https://doi.org/10.22146/jml.18789

Lestari, H., Jufri, N. 2018. Pendampingan Komunitas Perempuan Pemulung Melalui Pembentukan Family Educator Untuk Mewujudkan Keluarga Sadar Sehat (Kadarseh) dan Keluarga Sadar Gizi (Kadarzi) Sebagai Upaya Peningkatan Derajat Kesehatan Masyarakat di TPA Puuwatu Kota Kendari Sultra. Preventif Journal. 3(1):70-81.

Mothiba, M., Moja, S.J., Loans, C. 2017. A Review of the Working Conditions and Health Status of Waste Pickers at Some Landfill Sites in the City of Tshwane Metropolitan Municipality, South Africa. Advances in Applied Science Research. 8(3):90-97.

Mulyanasari, F., Mulyono, S. 2019. Pengumpul Sampah Perlu Mendapatkan Pelayanan Kesehatan Kerja: Literatur Review. Jurnal Endurance: Kajian Ilmiah Problema Kesehatan. 4(2):262-271. https://doi.org/10.22216/jen.v4i2.4161

Nisar, H., Ejaz, N., Naushad, Z., Ali, Z. 2008. Impacts of solid waste management in Pakistan: a case study of Rawalpindi city. WIT Transactions on Ecology and the Environment. 109(7):685-691. http://doi.org/10.2495/WM080701

Occupational Safety and Health Administration. 2004. Personal Protective Equipment. Washington: US Department of Labor.

Pardiansyah, R. 2015. Association Between Personal Protective Equipment with Contact Dermatitis in Scavengers. Majority (Medical Journal of Lampung University). 4(4):80-87. 